\title{
EFFICIENCY OF WINTER WHEAT FERTILIZATION SYSTEMS IN THE STEPPE ZONE OF SOUTHERN UKRAINE
}

\author{
Svitlana Burykina $^{1}$, Anna Kryvenko ${ }^{1 *}$, Ruslan Solomonov ${ }^{1}$, \\ Galina Kapustina $^{1}$, Antonina Drobitko ${ }^{2}$ \\ I*Odesa State Agricultural Research Station of NAAN, Ukraine; \\ ${ }^{2}$ Mykolaiv National Agrarian University, Ukraine;
}

*Corresponding Author Anna Kryvenko, e-mail: kryvenko35@ukr.net;

Received July 2021; Accepted August 2021; Published September 2021;

DOI: https://doi.org/10.31407/ijees11.420

\begin{abstract}
The results of the fifth and sixth rotations (2007-2020) of a long-term stationary experiment to study the effectiveness of various mineral fertilizer systems for growing winter wheat in the field crop rotation are summarized. The stationary experiment was established in 1971 on the southern low-humus heavy loam chernozem on forests. The natural and climatic zone is the Steppe; the agro-soil province is the dry Black Sea Steppe. Alternation of crops in the field crop rotation: black pair - winter wheat - winter rapeseed - winter wheat - sideral pair - winter wheat - winter wheat. The weighted average indicators of fertilizer efficiency in winter wheat crops were determined: $\mathrm{N}_{60} \mathrm{P}_{30-60} \mathrm{~K}_{30-60}$ - yield gave increase of 1,52 t/ha; energy efficiency coefficient was of 3,63; net profit was of 0,98 $\$ /$ ha; $\mathrm{N}_{120} \mathrm{P}_{30-60} \mathrm{~K}_{30-60}$ - yield gave increase of 2,04 t/ha; energy efficiency coefficient was of 2,41; net profit was of $0,79 \$ / \mathrm{ha} ; \mathrm{N}_{180} \mathrm{P}_{30-60} \mathrm{~K}_{30-60}$-yield gave increase of 2,22 t/ha; energy efficiency coefficient was of 2,09; net profit was of 0,69 \$/ha. For the zone of the Black Sea Steppe of Ukraine, the parameters of the payback of a unit of the active substance of mineral fertilizers are determined by the increments of the protein content in winter wheat grain, which on average amount to (mg/kg a. s.): $202 \mathrm{NPK} \mathrm{kg} / \mathrm{ha}$ and the ratio N:P:K = 2,5:1:1 - 10,68, $\mathrm{N}_{60}-$ $28,20, \mathrm{~N}_{120}-28,20$ and $\mathrm{N}_{180}-21,48$. It is shown that the systematic use of a complete mineral fertilizer with a total rate of $202 \mathrm{NPK} \mathrm{kg} / \mathrm{ha}$ and a ratio of N:P:K = 2,5:1:1 for black and sideral pairs provides winter wheat grain with a protein content of $14,18 \%$; winter rapeseed $-13,21 \%$ and $12,40 \%$ - for a stubble precursor. It is noted that at high and very high level of availability of available phosphorus and potassium in the southern chernozem, which was created in a stationary experiment during the years preceding the presented period (37 years), the maximum protein content in wheat grain is noted when $\mathrm{N}_{180}$ is applied: for black pairs $-14,84 \%$, for sidereal $-15,25 \%$, for winter rapeseed $-14,38 \%$ and for stubble predecessor $-13,86 \%$.
\end{abstract}

Keywords: winter wheat, mineral fertilizers, precursor, crop rotation, agrotechnical efficiency, economic and energy efficiency, net income. 